\title{
Kebijakan Pemerintah Daerah Kabupaten Purbalingga Dalam Menerapkan Lelang Jabatan Pada Tahun 2018
}

\author{
Dwi Husna Swastika ${ }^{1}$, Muhammad Eko Atmojo ${ }^{2}$, Vindhi Putri Pratiwi ${ }^{3}$ \\ 1,2,3 Ilmu Pemerintahan, Fakultas Ilmu Sosial dan Ilmu Politik, Universitas Muhammadiyah Yogyakarta \\ 2Email Korespondensi: atmojoeko91@gmail.com
}

\begin{abstract}
Abstrak: Jabatan Pemerintah Daerah Kabupaten Purbalingga Tahun 2018 terfokus pada bagaimana mekanisme yang terjadi selama proses Lelang Jabatan. Penelitian ini menggunakan metode kualitatif dengan data serta teori sebagai bahan penjelas. Pengumpulan data primer dilakukan secara wawancara dengan enam narasumber terkait sebagai data utama sedangkan data sekunder dilakukan secara dokumentasi sebagai data pendukung. Berdasarkan penelitian yang telah dilakukan bahwa Lelang Jabatan Pemerintah Kabupaten Purbalingga Tahun 2018 dilakukan berdasarkan sistem merit dan sesuai dengan regulasi pemerintah dari proses awal hingga akhir Lelang. Inovasi Lelang Jabatan dilakukan oleh Aparatur Sipil Negara dengan pertimbangan perekrutan berdasarkan sistem Manajemen Sumber Daya Manusia sesuai indikator kompetensi, profesionalitas dan kualitas melalui penilaian obyektif.
\end{abstract}

Kata kunci; Lelang Jabatan; Sistem Merit; Manajemen Sumber Daya Manusia.

Abstract: In this study regarding the Open Recruitment of the Regional Government of Purbalingga Regency in 2018 focused on the mechanism that occurs during the Open Recruitment or known as Open Selection process. This study uses qualitative methods with data and theory as explanatory material. Primary data collection is carried out in interviews with six related sources as the main data while secondary data is carried out in documentation as supporting data. Based on the research that has been done that the Open Selection of the Regional Government of Purbalingga Regency in 2018 is carried out based on the merit system and in accordance with government regulations from the initial process to the end of the Auction. Open Selection is conducted by Civil State Apparatus with consideration of recruitment based on the Human Resource Management system according to indicators of competence, professionalism and quality through objective assessment.

Keywords: Open Selection; Merit System; Human Resource Management.

Article History:

Received: 5-8-2020; Revised: 25-9-2020; Accepted: 10-10-2020

\section{PENDAHULUAN}

Lelang jabatan merupakan salah satu agenda reformasi birokrasi dibidang kepegawaian, mengingat sektor sumber daya manusia merupakan salah satu bagian terpenting dalam pelaksanaan reformasi birokrasi. Dengan adanya agenda reformasi birokrasi yang dilakukan oleh pemerintah maka terbitlah Undang-Undang Aparatur Sipil Negara, yang mana salah satu isi dari Undang-Undang tersebut adalah adanya mekanisme baru dalam penetuan pejabat struktural eselon II. Harapannya dengan adanya metode baru ini bisa meningkatkan kualitas pelayanan publik bagi masyarakat serta penentuan jabatan struktural sesuai dengan kompetensi bukan karena faktor politis maupun faktor yang lainnya.

Selain meningkatkan pelayanan publik terhadap masyarakat, metode baru ini juga diharapkan bisa menempatkan posisi jabatan sesuai dengan kompetensi pegawai. Dengan adanya penempatan pegawai sesuai dengan kompetensinya maka harapannya kedepan bisa lebih baik, terutama dalam memberikan pelayanan kepada masyarakat. Selama ini banyak sekali penempatan pegawai tidak didasari dengan kompetensi pegawai melainkan didasari oleh factor lain seperti kedekatan, maupun 
faktor politis. Sesuai dengan penelitian Azhari (2011) dalam (Burhanuddin \& Fatmawati, 2016) bahwa di Sulawesi Tenggara pengangkatan PNS dalam jabatan struktural lebih dominan kepentingan politik dari pejabat politik yang sedang berkuasa. Sedangkan penelitian Budiarjo (2011) dalam (Burhanuddin \& Fatmawati, 2016) menyatakan di Kabupaten Sleman Yogyakarta "bahwa usaha intervensi pejabat politik yang berlebihan diredam karena mengikuti para birokrat dalam hal mengangkat pejabat karier, di mana sekretaris daerah yang mengusulkan nama-namanya (sekda ketua Baperjakat) dan proses promosi selalu dirapatkan di Baperjakat.

Dengan banyaknya kasus intervensi politik dalam penentuan jabatan structural maka akan sangat merugikan masyarakat, selain itu pejabat yang menempati jabatan tersebut tidak sesuai dengan kualifikasi terutama kompetensi. Mengingat dalam penentuan jabatan structural kompetensi adalah salah satu indikator yang paling penting, karena dengan adanya kompetensi maka akan melahirkan kebijakan-kebijakan yang berintegritas serta memberikan pelayanan publik yang efektif bagi masyarakat. Mengingat jabatan structural eselon II merupakan salah satu jabatan yang sangat strategis dalam pengambilan kebijakan. Oleh karena itu, posisi tersebut perlu ditempati oleh seseorang yang mempunyai kompetensi dan bisa bekerja secara professional.

Pemerintah Kabupaten Purbalingga merupakan salah satu pemerintah yang menerapkan kebijakan lelang jabatan di tahun 2018. Adanya kebijakan ini diharapkan akan merubah skema penentuan jabatan struktural, sehingga penentuan jabatan structural tidak lagi berdasarkan factor kepentingan baik politik maupun yang lainnya serta tidak adanya faktor kedekatan dalam penentuan jabatan tersebut. Selain itu kebijakan ini juga diharapkan mampu untuk memberikan perubahan yang sangat mendasar terutama dalam pemberian layanan kepada masyarakat dan penempatan pegawai berdasarkan kompetensi.

Kekosongan jabatan yang terjadi pada tahun 2018 membuat Pemerintah Daerah Kabupaten Purbalingga mengambil langkah cepat dengan membuka lowongan pendaftaran calon pejabat structural eselon II. Dimana pada awal tahun 2018 ada 6 formasi jabatan sktruktural yang kosong, adapaun formasi jabatan tersebut adalah Kepala Badan Penelitian Pengembangan Daerah (Bappelitbangda), Kepala Dinas Pekerjaan Umum dan Penataan Ruang (DPUPR), dan Usaha Kecil Mikro (Dinkop UKM), Kepala Dinas Penanaman Modal dan Pelayanan Terpadu Satu Pintu (DPMPTSP) dan Kepala Dinas Penguatan Masyarakat dan Desa (Dinpermasdes). Dengan adanya kekosongan jabatan ini, kebijakan yang dikeluarkan oleh Pemerintah Kabupaten Purbalingga mengacu kepada Undang-Undang No 5 Tahun 2014 tentang Aparatur SIpil Negara. Dimana dalam pengisian lowongan jabatan struktural eselon II harus menggunakan metode lelang jabatan atau open bidding. Penerapan ini merupakan salah satu bentuk implementasi reformasi birokrasi, terutama reformasi birokrasi dibidang kepegawaian.

Manajemen Aparatur Sipil negara merupkaan bentuk reformasi birokrasi dalam penataan Aparatur Sipil Negara. Hal ini guna untuk mencipatakan paratur Sipil Negara yang kompeten, professional dan berintegritas. Salah satu bentuk manajemen Aparatur Sipil Negara dalam penataan pegawai dapat dilakukan melalui seleksi terbuka atau lelang jabatan. Seleksi terbuka merupakan mekanisme rekruitmen untuk menghasilkan kandidat yang terbaik melalui komoetisi yang transparan dan adil berdasarkan kompetensi yang dimiliki oleh masing-masing Aparatur Sipil Negara (Noors, 2019). Seperti pendapat (Nasir, 2019) bahwasannya seleksi terbuka bertujuan untuk memilih aparatur yang memiliki kapasitas komptensi dan integritas yang sesuai dengan kebutuhan jabatan yang lowong. Sehingga dengana danya seleksi terbuka ini menajdi salah satu manajemen sumber daya manusia untuk memilih Aparatur Sipil Negara yang sesuai dengan kualifikasi yang dibutuhkan pada jabatan yang kosong.

Adanya seleksi terbuka atau lelang jabatan ini akan mengubah pikiran masyarakat yang tadinya rekruitmen pegawai yang terkesan tertutup menjadi terbuka, sehingga seluruh Aparatur Sipil Negara dapat ikut serta. Seperti yang diungkapkan oleh (Herawati, 2016) bahwasannya seleksi terbuka atau lelang jabatan ini dilakukan secara transparan dimana membuka kesempatan bagi seluruh jabatan pimpinan tinggi untuk ikut serta dalam seleksi terbuka sesuai dengan kualifikasi yang dibutuhkan. Dengan adanya keterbukaan atau transparansi ini akan memberikan perubahan reformasi birokrasi yang semakin baik dalam proses penataan pegawai. Lelang jabatan atau seleski terbuka omo juga dapat mengurangi unsur-unsur patronase, nepotisme, korupsu maupun adanya intervensi politik dalam proses rekruitmen (Yahya \& Mutiarin, 2015). 
Seleksi tebruka ini sebanrnya sudah lebih dulu diterapkan di negara barat dengan istilah yang berbeda-beda untuk memilih aparattur yang memiliki kompetensi dan integritas yang memadai untuk mengisi jabatan tertentu (Nasir, 2019). Hal ini juga seperti penelitian yang dialkukan oleh (Rosmiati, Sumaryana, \& Buchari, 2019) bahwasannya pelaksanaan seleksi terbuka di Kota Bandung bertujuan untuk mendapatkan calon kandidat yang mempunyai kualifikasi sesuai dan nantinya akan berkompetisi untuk mendapatkan posisi pada jabatan yang ksosong. (Smith, 2013) juga mengatakan bahwasannya seleksi tebruka ini juga memberikan kesempatan bagi calon akndidat untuk ikut serta dalam proses seleksi dan memungkinkan calon kandidat tersebut memiliki latar belakang yang berbeda. Sehingga nantinya memang dengan adanya seleksi terbuka ini akan mampu menciptakan persaingan yang terbuka dan dapat menghasilkan calon akndidat yang sesuai.

Menurut (Rosmiati et al., 2019) terdapat 7 aspek keberhasilan dalam pelaksanaan seleksi tebruka yaitu, aspek kebijakan, aspek komunikasi, aspek transparansi, aspek panitia seleksi, aspek sistem merit dan aspek tantangan. Apabila suatu daerah dalam melaksanakan seleksi tebruka mampu menerpakan 7 aspek tersebut maka dapat dikatakan pelaksanaan seleksi tebruka di daerah tersebut berhasil. Akan tetapi, masih sering kita jumpai bahwasannya aspek sistem merit masih sukar untuk terealisakan karena dalam proses penentuan calon kandidat terkdang masih adana spoil sistem, dimana pemilihan kandidat berdasarkan factor kedekatan.

\section{METODE PENELITIAN}

Metode penelitian yang digunakan dalam penelitian ini adalah kualitatif. Penelitian kualitatif adalah penelitian yang bermaksud untuk memahami fenomena tentang apa yang dialami oleh subjek penelitian misalnya perilaku, cara deskripsi dalam bentuk kata-kata dan bahasa, pada suatu konteks khusus yang alamiah dan dengan memanfaatkan berbagai metode alamiah (Moleong, 2012). Penelitian ini dilakukan di Pemerintah Daerah Kabupaten Purbalingga Provinsi Jawa Tengah, dengan subyek penelitian adalah proses lelang jabatan pejabat struktural eselon II. Adapun narasumber dalam penelitian ini adalah Ketua Badan Kepegawaian Pendidikan dan Pelatihan Daerah, ketua bidang promosi dan mutasi, serta Aparatur Sipil Negara baik yang lolos seleksi maupun yang tidak lolos seleksi. Sedangkan untuk metode pencarian data yang digunakan dalam penelitian ini menggunakan wawancara dan data dokumentasi hasil seleksi terbuka pejabat struktural eselon II di lingkungan Pemerintah Kabupaten Purbalingga.

\section{HASIL DAN PEMBAHASAN}

Lahirnya Undang-Undang baru tentang Aparatur Sipil Negera merupakan salah satu bentuk reformasi birokrasi. Berdasarkan pernyataan Kumorotomo dkk (2010) dalam (Harahap, 2016) yang menyatakan bahwa ada beberapa permasalahan reformasi birokrasi di Indonesia diantaranya adalah sebagai berikut: Pertama, resistemsi birokrat terhadap reformasi birokrasi. Kedua, belum munculnya agenda reformasi yang terintegrasi mulai dari Pemerintah Pusat hingga ke Pemerintah Daerah, Ketiga, ketidakjelaskan landasan dalam proses rekruitmen pegawai, tidak nampak proses seleksi yang secara spesifik dapat dijadikan tolok ukur untuk merekrut pegawai sesuai dengan kebutuhan kompetensi formasi jabatan yang tersedia dalam organisasi pemerintah, Keempat, promosi yang tidak dilandasi profesionalisme. Meskipun reformasi birokrasi sudah dilaksanakan namun pola promosi pegawai di lingkungan pemerintah masih belum memiliki kejeleasan arah.

Jika kita Tarik kesimpulan dari beberapa permasalahan yang ada di atas, maka ada permasalahan yang sangat spesifik mengenai lahirnya Undnag-Undang Aparatur Sipil Negara, permasalahan tersebut adalah ketidak jelasanan landasan proses rekruitmen pegawai serta tidak jelasnya proses seleksi yang secara spesifik serta pelaksanaan promosi jabatan yang tidak dilandasi profesionalisme. Hal ini menjadi dasar yang sangat kuat untuk perubahan atau reformasi birokrasi di bidang kepegawaian. Dimana dengan adanya Undang-Undang baru maka salah satu agenda besar reformasi birokrasi dibidang kepegawaian adalah lahirnya system baru dalam proses promosi jabatan. Hal ini merupakan salah satu wujud implementasi reformasi birokrasi yang dilakukan oleh pemerintah, mengingat berdasarkan grand desain reformasi birokrasi ada 9 program percepatan reformasi birokrasi salah satunya adalah system promosi jabatan aparatur sipil negera (Nasir, 2019).

Sistem promosi yang selama ini terjadi adalah system promosi tertutup dan belum melakukan system promosi secara terbuka. Oleh karena itu, dengan adanya system promosi secara terbuka maka 
akan memberikan dampak positif bagi masyarakat maupun organisasi, diantaranya adalah munculnya inovasi-inovasi disektor pelayanan public maupun profesionalisme pegawai dalam bekerja. Selain itu, dengan adanya metode baru ini, penempatan jabatan struktural eselon II juga harus didasari dengan faktor kompetensi dan profesionalisme. Sehingga pejabat yang terpilih untuk menduduki jabatan structural eselon II merupakan pejabat yang mempunyai integritas dan profesionalisme dalam bekerja. Akan tetapi yang selama ini terjadi adalah penentuan jabatan structural eselon II bukan berdasarkan kompetensi maupun profesionalisme melainkan factor politis maupun kedekatan seseorang dengan calon. Hal ini senada dengan pernyataan dari (Daniarsyah, 2015) yang mengatakan bahwa sering sekali ditemukan pegawai atau birokrasi yang tidak netral, terutama bagi birokrasi di daerah dimana pegawai yang sudah lama bekerja dengan incumbent akan berusaha mendukung walaupun tidak secara terang-terangan kepada pejabat incumbent, hal ini dilakukan agar bisa mendapatkan jabatan.

Pengangkatan pejabat struktural seharusnya berdasarkan merit system, sehingga penempatan pegawai bisa sesuai dengan kompetensi dan kapabilitasnya, atau yang sering dikenal dalam manajemen sumber daya aparatur adalah the right man in the right place. Jika kita berbicara mengenai merit system maka berdasarkan pernyataan dari (Nasir, 2019) bahwa tujuan utama merit system adalah merekrut ASN yang profesional dan berintegritas dan menempatkan sesuai dengan jabatan-jabatan birokrasi pemerintah yang didasari dengan kompetensi, memberikan kompensasi kepada ASN yang layak dan adil, mengembangkan kemampuan ASN melalui bimbingan dan diklat, serta melindungi karir ASN dari politisasi dan kebijakan yang bertentangan dengan prinsip merit (nepotisme, primordialisme, dan bentuk diskriminasi lainnya).

Akan tetapai dalam realita yang terjadi banyak sekali penempatan pegawai yang tidak sesuai dengan merit system, sehingga penempatan pegawai lebih banyak berdasarkan faktor politik, kedekatan maupun kekeluargaan. Hal ini dikarenakan kepala daerah berdasarkan peraturan pemerintah nomor 96 tahun 2000 memungkinkan untuk mengangkat dan memberhentikan aparatur sipil negara di daerahnya dari aparatur sipil negara dengan pangkat I-a sampai dengan IV-e. Hal inilah yang menjadikan sebuah kendala dalam penempatan pejabat struktural yang sesuai dengan merit sistem, atau berdasarkan kompetensi.

Konsekuensi dari peraturan tersebut adalah sulitnya penerapan merit system bagi jabatan strategis seperti pejabat structural di lingkungan pemerintah daerah. Jika kita mengacu pada undangundang yang baru penerapan merit system memang harus diterapkan disemua sector pemerintahan, baik untuk jabatan structural eselon II maupun jabatan dibawahnya. Salah satu cara untuk menerapkan merit system adalah dengan diberlakukannya lelang jabatan atau seleksi terbuka bagi pejabat structural eselon II di lingkungan pemerintah baik ditingkat pusat maupun ditingkat provinsi serta kabupaten maupun kota. Dengan adanya metode ini harapannya penempatan pejabat structural tidak berdasarkan factor politik ataupun kedekatan melainkan melalui factor kompetensi dan profesionalisme.

Selain itu dengan adanya system lelang jabatan ini juga akan terbentuk system fairness dan transparansi yang lebih tinggi dalam penentuan jabatan structural eselon II. Mengingat pihak yang terlibat dalam proses pelaksanaan lelang jabatan terdiri dari pihak internal dan eksternal. Dimana pihak eksternal akan lebih fair dalam memberikan penilaian atau lebih objektif dalam menilai calon, selain itu pihak luar juga merupakan salah satu pihak yang sangat netral dan professional. Dengan adanya kompetisi yang fair tersebut maka akan menghasilkan pegawai yang memiliki kompetensi dan professional. Salah satu daerah yang menerapkan system ini adalah Pemerintah Kabupaten Purbalingga. Dimana pada tahun 2018 Pemerintah Kabupaten Purbalingga sudah mulai menerapkan system merit, terutama dalam tahapan seleksi terbuka pejabat structural eselon II. Berdasarkan lelang jabatan yang telah dilaksanakan maka ada beberapa mekanisme dalam penentuan pejabat structural diantaranya adalah sebagai berikut:

\section{Identifikasi Kekosongan Jabatan dan Pembentukan Panitia Seleksi}

Pada tahap awal pemerintah Kabupaten Purbalingga melalui Badan Kepegawaian Pendidikan dan Pelatihan Daerah (BKPP) melakukan identifikasi kekosongan jabatan. Adapun tujuan dari identifikasi jabatan ini adalah untuk mempermudah BKPP dalam penyusunan formasi jabatan. Dimana dari hasil identifikasi tersebut terdapat 6 kekosongan jabatan structural di lingkungan Pemerintah Kabupaten Purbalingga. Adapun jabatan yang kosong tersebut adalah sebagai berikut: Kepala Badan Penelitian Pengembangan Daerah (Bappelitbangda), Kepala Dinas Pekerjaan Umum 
dan Penataan Ruang (DPUPR), dan Usaha Kecil Mikro (Dinkop UKM), Kepala Dinas Penanaman Modal dan Pelayanan Terpadu Satu Pintu (DPMPTSP) dan Kepala Dinas Penguatan Masyarakat dan Desa (Dinpermasdes).

Setelah tersusun formasi jabatan yang akan di informasikan dan di isi melalui lelang jabatan maka Pemerinah Kabupaten Purbalingga melalui BKPP melakukan pembentukan panitia seleksi. Adapun komposisi panitia seleksi ini diantaranya terdiri dari 1 (satu) panitia internal, 2 (dua) terdiri dari akademisi, dan 2 (dua) terdiri dari tokoh masyarakat. Dengan komposisi seleksi yang terdiri dari 5 orang ini harapannya akan bisa menetralisir factor-faktor politis maupun kedekatan dalam pemeilihan pejabat structural. Selain itu penentuan komposisi panitia ini juga diharapkan bisa menerapkan system merit sesuai amanah undang-undang aparatur sipil negara maupun grand desain reformasi birokrasi di bidang kepegawaian terutama dalam hal promosi jabatan.

Penunjukkan panitia yang terdiri dari internal dan eksternal ini juga diharapkan bisa menjaga sisi profesionalisme serta dapat menilai secara objektif bagi para calon pejabat structural. Sehingga pejabat yang didapatkan merupakan pejabat yang mempunyai kompetensi dan professional dalam bekerja. Sehingga pejabat yang menduduki jabatan tersebut tidak terbebani dengan kepentingankepentingan segelintir orang maupun golongan. Dengan begitu kebijakan yang akan dikeluarkan merupakan kebijakan yang memihak kepada masyarakat. Berikut adalah panitia seleksi yang terpilih dalam pelaksanaan seleksi terbuka pejabat structural eselon II di lingkungan Pemerintah Kabupaten Purbalingga pata tahun 2018.

Tabel 1. Susunan Panitia Seleksi Terbuka JPT Pratama di Kabupaten Purbalingga 2018

\begin{tabular}{|c|l|l|c|}
\hline No & \multicolumn{1}{|c|}{ Nama } & \multicolumn{1}{|c|}{ Jabatan } & $\begin{array}{c}\text { Kedudukan Dalam } \\
\text { Pansel }\end{array}$ \\
\hline $\mathbf{1}$ & Tasdi, SH,MM & Bupati Purbalingga & Pengarah \\
\hline $\mathbf{2}$ & Dyah Hayuning Pratiwi, SE,B.Econ & Wakil Bupati Purbalingga & Wakil Pengarah \\
\hline $\mathbf{3}$ & $\begin{array}{l}\text { Prof. Dr. H. Muhammad Fauzan, SH, } \\
\text { M.Hum }\end{array}$ & $\begin{array}{l}\text { Guru Besar Universitas } \\
\text { Jenderal Soedirman }\end{array}$ & Ketua \\
\hline $\mathbf{4}$ & Wahyu Kontardi, SH & Sekretaris Daerah & Anggota \\
\hline $\mathbf{5}$ & Prof. Dr. Paulus Israwan Setyoko, MS. & $\begin{array}{l}\text { Guru Besar Universitas } \\
\text { Jenderal Soedirman }\end{array}$ & Anggota \\
\hline $\mathbf{6}$ & Trisnanto Srihutomo, BE, S.Pd & $\begin{array}{l}\text { Anggota Dewan Pendidikan } \\
\text { Kab.Purbalingga }\end{array}$ & Anggota \\
\hline $\mathbf{7}$ & Purwanto, SH. MM & Profesional & Anggota \\
\hline
\end{tabular}

Sumber: Keputusan Bupati Purbalingga Nomor: 800.325.1 Tahun 2017

Setelah terbentuknya formasi jabatan dan komposisi kepanitiaan maka langkah selanjutnya yang harus dilakukan adalah melakukan penyebaran informasi formasi ke media maupun pemerintah daerah lainnya. Hal ini dilakukan guna menjaring dan mendapatkan aparatur sipil negara yang memiliki kompetensi dan professional. sehingga aparatur sipil negara yang terpilih merupakan orangorang pilihan yang dapat menciptakan pelayanan public serta mengambil kebijakan yang memihak kepada masyarakat. Adapun formasi yang tersedia di sebarluaskan melalui media cetak, online seperti website resmi maupun surat resmi kesetiap OPD dilingkungan Pemerintah kabupaten Purbalingga maupun Pemerintah Provinsi dan Pemerintah Kabupaten lainnya di Jawa tengah.

Dengan adanya informasi tersebut, maka membuka kesempatan bagi aparatur sipil negara untuk dapat mengikuti seleksi terbuka yang diadakan oleh Pemeirntah Kabupaten Purbalingga. Adanya seleksi terbuka ini juga dapat memberikan kesempatan bagi aparatur sipil negara yang akan meningkatkan jenjang karirnya. Akan tetapi, aparatur sipil negara yang dapat mengikuti seleksi terbuka ini hanya mereka yang memiliki syarat yang telah disampaikan di pengumuman yang ada. Berdasarkan informasi yang telah disebarkan, ada sekitar 50 aparatur sipil negara yang ikut mendaftar dalam proses seleksi tebruka untuk pengisian 6 formasi jabatan yang kosong di Lingkungan Pemerintah Kabupaten Purbalingga. Pada tahapan admnistrasi ini, ada beberapa syarat yang yang harus dilengkapi oleh pendaftar diantaranya adalah sebagai berikut: (1) surat lamaran, (2) daftar riwayat hidup, (3) SK Pangkat (fotokopi), (4) SK Jabatn (fotokopi), (5) Ijazah (fotokopi), (6) STTPL Diklat PIM III (fotokopi), (7) Surat keterangan sehat, (8) SKP/DP-3 (fotokopi), (9) Surat pernyataan tidak dijatuhi hukuman disiplin, (10) Surat persetujuan dan AL/PPK, (11) Pas foto. 
Setelah aparatur sipil negara melengkapi berkas syarat seleksi terbuka, maka aparatur sipil negara harus mengirimkan berkas lamaran secara langsung ke Badan Kepegawaian Pendidikan dan Pelatihan Daerah Kabupaten Purbalingga. Setelah adanya berkas lamaran masuk, maka panitia seleksi terbuka akan melakukan seleksi administrasi. Dimana pada proses seleksi administrasi ini, panitia akan menyeleksi kelengkapan syarat seleksi, hal ini dilakukan guna untuk mendapatkan aparatur sipil negara yang berkompeten dan professional. Dengan adanya proses seleksi administrasi yang ketat maka diharapkan akan terjaring aparatur sipil negera yang mempunyai kompetensi tinggi. Mengingat seleksi administrasi merupakan salah satu bentuk proses penilaian pada pelaksanaan seleksi terbuka atau lelang jabatan.

Dari proses seleksi yang telah dilakukan oleh panitia ada beberapa peserta yang dinyatakan lolos dan dinyatakan tidak lolos. Hal ini dituangkan juga dalam keputusan panitia seleksi terbuka jabatan pimpinan tinggi pratama Pemerintah Kabupaten Purbalingga Nomor: 821/06/Pansel/II/2018, bahwa dari total keseluruhan pendaftar yang ada ada sekitar 40 pedaftar yang dinaytakan lolos seleksi administrasi. Sedangkan untuk 10 peserta lainnya dinyatakan tidak lolos seleksi administrasi. Adapun faktor yang menyebabkan peserta lelang jabatan pimpinan tinggi pratama tidak lolos administrasi adalah ketidaklengkapan data yang dibawa.

\section{Proses Assessment}

Setelah dilakukannya seleksi administrasi maka tahap berikutnya adalah proses assessment atau penilaian bagi calon pejabat structural. Dimana pada proses penilaian ini panitia ini panitia seleksi akan bekerja sama dengan pihak ketiga, sehingga proses penilaian bisa berjalan dengan baik dan yang paling tepat adalah menjaga nilai-nilai objektifitas atau menjunjung tinggi system merit. Selain itu proses assessment ini merupakan salah satu tahapan di dalam proses seleksi terbuka yang dilakukan oleh Pemerintah Kabupaten Purbalingga guna untuk menghasilkan aparatur sipil negara yang memiliki kompetensi dan sesuai dengan kebutuhan organisasi.

Pada tahapan assessment ini, panitia seleksi bekerjasama dengan pihak luar yaitu akademisi dari Universitas Katolik Soegijapranata, hal ini guna untuk meminimalisir adanya kecurangan atau penilaian yang subyektif terhadap peserta calon pejabat struktural. Mengingat proses promosi jabatan struktural yang selama ini terjadi sifatnya lebih tertutup dan tidak terbuka seperti kebijakan dari undang-undang aparatur sipil negara yang baru. Dengan adanya kebijakan yang melibatkan pihak ketiga ini akan sangat baik bagi instasisi maupun bagi aparatur sipil negara. Dimana untuk organisasi atau instansi akan lebih banyak varian dalam melaksanakan proses lelang jabatan sedangkan bagi aparatur sipil negara peta karirnya akan lebih jelas dan terbuka.

Selain melakukan kerjasama dengan pihak ketiga pelaksanaan seleksi terbuka bagi jabatan tinggi pratama di lingkungan Pemerintah Kabupaten Purbalingga juga menerapkan beberapa tahapan tes. Adapaun tahapan tes yang telah dilakukan diantaranya adalah seleksi administrasi, melakukan ujian tertulis, wawancara, dan penulisan karya tulis ilmiah. Tahapan ini dilakukan guna mencari sumber daya aparatur yang memang mempunyai kapasitas maupun kualitas, terutama calon pejabat yang mempunyai kompetensi. Kegiatan tes ini juga dilakukan oleh panitia seleksi yang bekerjasama dengan pihak ketiga yaitu Universitas Katolik Soegijapranata, mengingat universitas tersebut merupakan salah satu universitas yang sudah mempunyai fasilitas dengan baik salah satunya adalah memiliki Laboratorium Psikodiagnostika.

Metode lelang jabatan atau seleksi terbuka ini merupakan salah satu kebijakan Pemerintah Kabupaten Purbalingga yang mengimplementasikan grand desain reformasi birokrasi. Selain itu metode ini juga salah satu bentuk implementasi system merit di sector pemerintahan. Berdasarkan pernyataan dari (Sahambangung, Pioh, \& Waworundeng, 2019) bahwa sistem mengubah manajemen ASN dengan berdasarkan pada kualifikasi, kompetensi, dan kinerja, selain itu sistem ini juga akan melakukan penilaian secara adil dan wajar, tanpa membedakan latar belakang politik, ras, warna kulit, agama, asal-usul, jenis kelamin, status pernikahan, umur, ataupun kondisi kecacatan.

Proses assessment merupakan salah satu bentuk atau model penilaian yang digunakan dalam lelang jabatan. Dimana dalam penilaian ini ada beberapa kriteria yang harus dilakukan, diantaranya adalah ujian tertulis, wawancara dan penulisan karya tulis ilmiah. Dengan komponen tersebut harapannya sumber daya aparatur yang didapat merupakan sumber daya aparatur yang mempunyai kompetensi dan professional dalam bekerja. Mengingat profesionalisme dan kompetensi bagi setiap pegawai merupakan hal yang sangat mutlak untuk dimiliki, terutama bagi pejabat structural eselon II. 
Hal ini dikarenakan pejabat structural eselon II meruapakan jabatan strategis yang memiliki pengaruh sangat besar, baik dari sisi pembuat kebijakan maupun pengambilan kebijakan.

Setelah dilakukannya proses assessment maka panitia seleksi akan mengumumkan hasil lelang jabatan. Dimana hasil yang diumumkan ini merupakan gabungan dari semua kegiatan tes yang diikuti oleh para peserta. Nilai yang diperoleh peserta diambilkan dari perolehan akumulatif nilai tes assessment yang telah dilakukan. Dimana dari penilaian yang telah dilakukan maka akan diambil menjadi 3 besar yaitu peserta yang memperoleh nilai tertinggi dari urutan pertama sampai ketiga. Sedangkaan untuk peserta yang memperoleh urutan keempat dan seterusnya tidak diambil dan dinyatakan tidak bisa mengikuti tahap berikutnya.

Berikut adalah nama-nama peserta yang dinyatakan lolos 3 besar dan siap untuk mengikuti tahap berikutnya. Hal ini dituangkan dalam Keputusan Panitia Seleksi Terbuka Jabatan Pimpinan Tinggi Pratama Pemerintah Kabupaten Purbalingga Nomor: 821/12/Pansel/II/2018 dengan hasil penilaian akhir sebagai berikut:

Table 2. Peserta Dinyatakan Lolos Seleksi Terbuka

\begin{tabular}{|c|l|c|}
\hline \multicolumn{1}{|l|}{ Dinas Pendidikan Dan Kebudayaan Nama } & Total Nilai \\
\hline No & \multicolumn{1}{|l|}{} & 80,61 \\
\hline $\mathbf{1}$ & Jiah Palupi Twiyantarti, Dra, MM & 79,08 \\
\hline $\mathbf{2}$ & Sarjono, S.Pd, M.Si & 76,87 \\
\hline $\mathbf{3}$ & Bangun Pracoyo, S.Pd, M.Pd & 78,70 \\
\hline Dinas Pekerjaan Umum Dan Penataan Ruang & 78,40 \\
\hline $\mathbf{1}$ & Cahyo Rudiyanto, ST & 77,73 \\
\hline $\mathbf{2}$ & Priyo Satmoko, SH, MH & \\
\hline $\mathbf{3}$ & Wahyu Prasetyono, S.I & 78,98 \\
\hline Dinas Pemberdayaan Masyarakat Dan Desa & 77,73 \\
\hline $\mathbf{1}$ & Suroto, Drs, M.Si & 77,50 \\
\hline $\mathbf{2}$ & Bambang Sukendro, S.Sos & 79,10 \\
\hline $\mathbf{3}$ & Mohammad Najib, Drs, M.Si & 75,56 \\
\hline Dinas Penanaman Modal Dan Pelayanan Perijinan Terpadu Satu Pintu \\
\hline $\mathbf{1}$ & Edhy Suryono, S.Sos, M.Si & 75,10 \\
\hline $\mathbf{2}$ & Satya Giripodo, Drs & \\
\hline $\mathbf{3}$ & Eni Sosiatman, S.Sos, M.Si & 80,02 \\
\hline Dinas Koperasi Usaha Kecil Dan Menengah & 76,76 \\
\hline $\mathbf{1}$ & Budi Susetyono, Drs, M.Si & 76,36 \\
\hline $\mathbf{2}$ & Bambang Widionarko, Drs, M.Si & \\
\hline $\mathbf{3}$ & Mukodam, S.Pt & \\
\hline Sumber: Keputusan Panitia Seleksi Terbuka Jabatan Pimpinan Tinggi Pratama Pemerintah Kabupaten Purbalingga \\
\hline
\end{tabular}

Hasil keputusan keputusan panitia seleksi terbuka tersebut bukanlah keputusan final, mengingat masih ada proses yang akan di lakukan oleh pemerintah daerah, adapun proses selajutnya adalah melakukan koordinasi dengan Komisi Aparatur Sipil Negara. Dimana hasil keputusan panitia yang telah disahkan dalam surat keputusan akan diberikan kepada Bupati selaku Pejabat Pambina Kepegawaian. Hal ini dilakukan karena Bupati mempunyai kewenangan untuk melakukan koordinasi dan menentukan siapa saja yang akan menjadi pejabat struktural dilingkungan Pemerintah Kabupaten Purbalingga.

Berdasarkan surat keputusan panitia tersebut maka Bupati melakukan koordinasi dengan Komisi Aparatur Sipil Negara denan cara mengirimkan nama-nama peserta setiap dinas yang masuk 3 besar. Nama-nama tersebut akan dimintai rekomendasi maupun pertimbangan pilihan dari Komisi Aparatur Sipil Negara. Menurut Peraturan KASN Nomor 8 Tahun 2016 tentang Sistem Informasi Monitoring Tindak Lanjut Rekomendasi bahwa Rekomendasi adalah surat yang dikeluarkan KASN yang bersifat mengikat untuk menyetujui, menyetujui dengan perbaikan atau menolak pengajuan rencana seleksi atau laporan hasil seleksi dari instansi pemerintah yang akan atau telah melaksanakan seleksi terbuka Jabatan Pimpinan Tinggi. 
Rekomendasi dari KASN bukanlah hal yang mutlak untuk dilakukan, mengingat KASN hanya memberikan rekomendasi dan pertimbangan saja. Akan tetapi yang mempunyai kewenangan untuk memlih dari 3 peserta tersebut adalah Bupati. Hal ini ditegaskan dalam Undang-Undang Nomor 5 Tahun 2014 tentang Aparatur Sipil Nengara yang menyatakan bawha berdasarkan pasal 115 ayat 4 bahwa PPK selaku Bupati dapat memilih 1 (satu) dari 3 (tiga) nama calon JPT Pratama yang telah diseleksi untuk ditetapkan dan dilantik dengan catatan bahwa dalam melakukan penetapan agar memperhatikan hasil penilaian dari Pansel.

Setelah dilakukan terpilih dari 3 calon menjadi 1 calon maka langkah selanjutnya adalah melakukan pelantikan. Pemilihan 1 calon tersebut merupakan hasil dari beberapa penilianan yang telah dilakukan, salah satu penilaian tambahan adalah dengan melakukan penilianan rekam jekak peserta, pengalaman selama menjabat di kantor pemerintahan, prestasi yang dimiliki, keterampilan, serta pendidikan yang telah diampu. Dengan adanya penilaian secara objektif maka harapannya sumber daya aparatur atau pejabat struktural yang menempati jabatan merupakan orang-orang yang mempunyai kompetensi dan profesional. Sehingga bisa mengembangkan organisasi tersebut dengan baik, selain itu juga bisa melakukan pengambilan kebijakan yang berpihak kepada masyarakat dan bukan berpihak kepada sekelompok orang ataupun individu.

Jika kita berbicara mengenai seleksi terbuka yang dilakukan oleh Pemerintah Kabupaten Purbalingga, hal ini merupakan hal yang sangat baru dan bermanfaat untuk meningkatkan kualitas sumber daya manusia di lingkungan pemerintah. Akan tetapi jika kita tarik berdasarkan teori yang ada maka proses seleksi terbuka ini merupakan hal yang baik tetapi masih banyak sekali kekurangannya. Diantaranya adalah masih tingginya kewenangan pejabat pembina kepegawaian dalam menentukan calon pejabat struktural. Mengingat jabatan struktural adalah jabatan yang sangat strategis dan merupakan jabatan teknokrat, sedangkaan pejabat pembina kepegawaian merupakan jabatan politik yang syarat akan kepentingan.

Jika kita lihat pada saat ini memang birokrasi kita masih tergolong kategori birokrasi model birokrasi Marxis dan Executive Ascendency, dimana dengan model seperti ini maka akan sulit sekali untuk memisahkan politik dengan birokrasi. Hal ini senada dengan pernyataan dari (Katharina, 2018) yang menyatakan bahwa model birokrasi Marxis dan Executive Ascendency justru akan menempatkan birokrasi Indonesia semakin kuat dalam cengkraman politik serta hubungan patron-klien akan terus terjaga. Oleh karena itu perlu ada kebijakan baru yang dikeluarkan oleh pemerintah dalam hal penanganan sumber daya manusia terutama dalam hal penentuan jabatan struktural eselon II.

Demi terwujudnya reformasi birokrasi khususnya dalam bidang kepegawaian maka yang harus dilakukan adalah pengurangan maupun penghapusan kewenangan yang dimiliki oleh pejabat pembina kepegawaian. Serta penentuan jabatan struktural bukan lagi diserahkan kepada pejabat pembina kepegawaian melainkan diserahkan kepada pejabat karier birokrasi. Hal ini menurut saya akan lebih fair dan sangat minim dengan kepentingan politik atau kepentingan yang lainnya, selain itu juga bisa menerapkan sistem merit dengan baik dan sesuai dengan pengertian sistem merit.

\section{KESIMPULAN}

Berdasarkan analisis diatas maka dapat disimpulkan bahwa model lelang jabatan merupakan salah satu komponen baru dalam mewujudkan merit sistem. Dimana dengan adanya lelang jabatan atau seleksi terbuka ini harapannya sumber daya aparatur yang didapatkan merupakan sumber daya yang mempunyai kompetensi dan profesional dalam bekerja. Sehingga model ini merupakan model yang sangat bagus untuk diterapkan, dan kebijakan yang diambil oleh Pemeirintah Kabupaten Purbalingga merupakan kebijakan yang sangat tepat. Selain itu dalam proses seleksi terbuka Pemerintah Kabupaten Purbalingga melakukan pembentukan panitia yang terdiri dari eksternal dan internal serta melakukan kerjasama dengan pihak ketiga terutama Universitas, hal ini dilakukan demi terciptanya penilaian yang objektif. Selain itu proses seleksi terbuka ini juga dilakukan sesuai dengan peraturan yang berlaku baik Undang-Undang maupun Peraturan lain yang berkaitan dengan proses seleksi terbuka.

Pemberlakukan seleksi terbuka bagi pejabat struktural merupakan salah satu hal yang harus dilakukan oleh setiap daerah demi mendapatkan sumber daya aparatur yang memiliki kompetensi. Walupun dalam proses penerapan ini masih banyak sekali kelemahan diantaranya adalah masih sangat tingginya kewenangan pejabat pembina kepegawaian dalam memilih calon pejabat struktural. 
Walaupun hal ini sudah dilakukan melalui seleksi terbuka, akan tetapi dalam pemilihan 3 besar menjadi satu calon masih ada kelemahan karena msih bersifat tertutup.

\section{REFERENSI}

Burhanuddin, \& Fatmawati. (2016). Dominasi Aktor pada Pelaksanaan Mutasi Pejabat Karier dalam Birokrasi Pemerintahan di Kota Makassar (Kajian Lelang Jabatan atau Open Recrutment). Seminar Nasional Administrasi Negara II. Retrieved from https://s3.amazonaws.com/academia.edu.documents/53039012/Dominasi_Aktor_Bur_Makassa r1.pdf?response-content-disposition=inline\%3B

filename\%3DDominasi_Aktor_pada_Pelaksanaan_Mutasi_P.pdf\&X-Amz-Algorithm=AWS4HMAC-SHA256\&X-Amz-Credential=AKIAIWOWYYGZ2Y53UL3

Daniarsyah, D. (2015). Bureaucratic Political And Neutrality Of Bureaucracy In Indonesia. Jurnal Ilmu Politik Dan Komunikasi, V(2), 85-94.

Harahap, N. A. (2016). Penguatan Kedudukan Dan Peran Komisi Aparatur Sipil Negara Dalam Mewujudkan Reformasi Birokrasi. Jurnal Panorama Hukum, 1(2), 83. https://doi.org/10.21067/jph.v1i2.1418

Herawati, N. R. (2016). Evaluasi Lelang Jabatan Camat dan Lurah Pemerintah Provinsi DKI Jakarta. Jurnal Ilmiah Ilmu Pemerintahan, 2(2), 51-60. Retrieved from https://ejournal2.undip.ac.id/index.php/jiip/article/view/2122

Katharina, R. (2018). Reformasi Manajemen Aparatur Sipil Negara: Evaluasi Peran Pejabat Pembina Kepegawaian dan Komisi Aparatur Sipil Negara. Jurnal Spirit Publik, 13(2), 1-16. https://doi.org/10.1017/CBO9781107415324.004

Moleong, L. J. (2012). Metodologi Penelitian Kualitatif(Ed). Bandung: PT. Remaja Rosdakarya.

Nasir. (2019). Implementasi Kebijakan Seleksi Terbuka Dalam Pengisian Jabatan Pimpinan Tinggi Pratama di Lingkup Pemerintahan Kabupaten Toraja Utara. Jurnal Administrasi Publik, 5(2), 154-174.

Noors, A. I. A. (2019). Analisis Pelaksanaan Seleksi Terbuka bagi Pengisian Jabatan Pimpinan Tinggi di Indonesia. Konferensi Nasional Ilmu Administrasi, 1-6.

Rosmiati, M., Sumaryana, A., \& Buchari, A. (2019). REKRUTMEN TERBUKA JABATAN PIMPINAN TINGGI PADA BADAN KEPEGAWAIAN DAERAH KOTA BANDUNG. Jurnal Administrasi Publik (JAP), 9(2), 228-243.

Sahambangung, O., Pioh, N., \& Waworundeng, W. (2019). Manajemen Sistem Aparatur Sipil Negara (Studi tentang Sistem Merit dalam penempatan jabatan pimpinan tertinggi di lingkungan pemerintahan kabupaten kepulauan sangihe). Eksekutif Jurnal Ilmu Pemerintahan, 3(3), 1-13.

Smith, D. M. (2013). Candidate Recruitment for the 2012 Election: New Parties, New Methods ... Same Old Pool of Candidates? New york: Palgrave Macmillan.

Yahya, M. R., \& Mutiarin, D. (2015). Model Lelang Jabatan Di Pemerintah Daerah Daerah. Jurnal Ilmu Pemerintahan \& Kebijakan Publik, 2(2). 